\title{
Recombinant immunotoxin anti-c-Met/PE38KDEL inhibits proliferation and promotes apoptosis of gastric cancer cells
}

\author{
Xu Wei ${ }^{1}$, Zhu Xiao Juan ${ }^{1}$, Feng Xiao Min², Cai Nan ${ }^{1}$, Zhang Xiu Hua ${ }^{1}$, Feng Zheng Qing ${ }^{2}$ and Liu Zheng ${ }^{1 *}$
}

\begin{abstract}
Background: Our study aims to evaluate the anti-growth effects of recombinant immunotoxin (IT) anti-c-Met/ PE38KDEL on gastric cancer cells, and its mechnisms.

Methods: Gastric cancer cells were treated with increasing doses of IT and c-Met protein was quantified by Western blotting. Cell proliferation was determined by Cell Counting Kit-8 assay (CCK). [ $\left.{ }^{3} \mathrm{H}\right]$-leucine incorporation assay was used to evaluate IT inhibition of protein synthesis. Cell apoptosis was quantified by flow cytometry. Caspase activities were measured using colorimetric protease assays.

Results: Cell growth and protein synthesis of the gastric cancer cell lines were suppressed by IT in a dose- and time-dependent manner. IT also induced apoptosis in a dose-dependent manner. The apoptosis rates of gastric cancer cell lines MKN-45 and SGC7901 were $19.19 \%$ and 27.37\%, respectively when treated with $50 \mathrm{ng} / \mathrm{ml}$ of IT. There were significant increase ofcaspase-3 activity at $24 \mathrm{hr}$ of IT treatment $(100 \mathrm{ng} / \mathrm{ml})(P<0.01)$ in these gastric cancer cell lines.

Conclusions: IT anti-c-Met/PE38KDEL has anti-growth effects on the gastric cancer cell lines in vitro, and it provides an experimental basis for c-Met-targeted therapy towards in vivo testing.
\end{abstract}

\section{Introduction}

Gastric carcinoma (GC) is one of the most common and lethal malignant cancers [1]. Despite the improving surgical techniques and new chemotherapeutic treatment regimens, the patient survival rate remains dismal [2], and effective alternative treatment approach is in vital need. GC has been shown to harbor multiple somatic mutations as well as over-expressions of oncoproteins. Identification of these $\mathrm{GC}$-associated biomarkers may entail possible discovery of new therapeutic targets [3]. Among various GC-associated biomarkers, c-MET gene is frequently found gnomically-amplified and overexpressed in GC cell lines [4]. The proto-oncogene cMET, a receptor of hepatocyte growth factor (HGF, also known as scatter factor), encodes a $190 \mathrm{kDa}$ heterodimeric transmembrane tyrosine kinase. HGF binding to c-Met triggers tyrosine kinase domain auto-

\footnotetext{
* Correspondence: liuzheng117@126.com

'Department of Gastroenterology, The Second Affiliated Hospital of Nanjing Medical University, Nanjing, 210029, PR China

Full list of author information is available at the end of the article
}

phosphorylation and induces pleiotropic responses such as proliferation, motility, morphogenesis and angiogenesis in many cell types including normal and tumor cells [5]. c-MET amplification has been identified in nearly $74 \%$ of human GC specimens [6]. HGF and c-MET both play important roles in the progression and metastasis of GC [7]. Thus, c-Met has been considered as a promising therapeutic target for various cancers.

Immunotoxins (ITs) are fusion proteins composed of a toxin fused to an antibody or growth factor with distinct target specificity [8]. IT exerts its anti-growth effect by inhibiting protein synthesis and promoting apoptosis [9]. IT anti-c-Met/PE38KDEL (anti-c-Met Fab, which resulted from screening and characterization from a natural human Fab phage antibody library; PE38KDEL, which is a modified structure of PE38, lost the function of combining with non-mammalian cells specifically, but retained a complete cytotoxicity after internalization) has shown specific cytotoxic effects against c-Met-positive cancer cells [10]. In this study, we investigated the effects of IT anti-c-Met/PE38KDEL on proliferation and

\section{() Biomed Central}


apoptosis of two different c-Met-positive malignant gastric cell lines, MKN-45 and SGC7901 [11,12], and a normal gastric mucosa cell GES-1 [13]. We found that IT anti-c-Met/PE38KDEL exerts its anti-growth effect primarily through rapid inhibition of protein synthesis.

\section{Materials and Methods}

\section{Immunotoxin}

IT anti-c-Met/PE38KDEL was described previously [9]. It induces apoptosis in hepatic carcinoma cells SMMC7721. Cell Counting Kit 8 (CCK8) was purchased from Sigma Chemical. Caspase colorimetric assay kit and anti-caspase3 antibody were from Biovision. Antibodies against c-Met and $\beta$-actin were purchased from Santa Cruz. Protein lysis buffer was from TaKaRa Biotechnology.

\section{Cell culture}

GC cells lines, MKN-45 and SGC7901, and normal gastric mucosa cells GES-1 were obtained from the Cell Bank of Type Culture Collection of the Chinese Academy of Sciences (Shanghai, China), and were grown in DMEM (Invitrogen) supplemented with $10 \%$ fetal calf serum (FCS) and incubated at $37^{\circ} \mathrm{C}$ with $5 \% \mathrm{CO}_{2}$. All cell lines were routinely tested and found to be free from mycoplasma contamination.

\section{Western Blotting}

GES-1, MKN-45 and SGC7901 cells grown in 6-well plates were collected in lysis buffer for total cellular protein. Protein concentrations were measured using a Bradford reagent (Bio-Rad). Equal amounts of protein (80 $\mathrm{g}$ /lane) from each cell line were boiled for $5 \mathrm{~min}$, separated by SDS-PAGE, and then transferred on to a nitrocellulose membrane before blocking in 5\% non-fat dried milk in Tris-buffered saline (TBS) for $120 \mathrm{~min}$ at room temperature. The membranes were then incubated with a primary anti-human c-Met polyclonal antibody (diluted 1:150 in a new batch of the blocking buffer) or a goat polyclonal primary anti- $\beta$-actin (diluted 1:1000, Santa Cruz, CA, USA) for $2 \mathrm{hr}$ and followed by incubation with peroxidase-labelled anti-IgG secondary antibody for $1 \mathrm{hr}$. After washing with TBST for 3 times, the films were developed and the protein bands were quantified by densitometry using ImageJ software (NIH, Bethesda, MD, USA).

To detect the caspase- 3 activity, both floating and adherent cells were collected $24 \mathrm{hr}$ following IT treatment. Total cellular protein was prepared as described above. All the experiments were performed at least twice with similar results.

\section{Cell proliferation assay}

Cell growth inhibition rate (IR) was determined using a CCK- 8 assay following the manufacturer instructions
(Sigma). GES-1, MKN-45 and SGC7901 cells were seeded at a concentration of $1 \times 10^{5}$ cells/90 $\mu \mathrm{l} /$ well in 96-well culture plates. After incubation of cells with the indicated concentrations of IT for $24 \mathrm{hr}$ and $48 \mathrm{hr}, 10$ $\mu \mathrm{l} /$ well of cell Counting Kit- 8 solution was added to the medium and the cells were incubated for an additional $4 \mathrm{hr}$. The absorbance at $450 \mathrm{~nm}$ was then measured in a Microplate Reader. IR was calculated using the following equation: $\mathrm{IR}=[1-(A$ value in the treated samples- $A$ value in the blank samples) / ( $A$ value in the control samples- $A$ value in the blank samples)] $* 100 \%$. The assays were performed in triplicates and repeated at least twice [14].

\section{Protein synthesis inhibition assay}

IT-induced inhibition of protein synthesis in GES-1, MKN-45 and SGC7901 cells were evaluated using the $\left[{ }^{3} \mathrm{H}\right]$-leucine incorporation assay [15]. Cells were seeded in 48 -well plates $\left(1 \times 10^{4}\right.$ per well $)$ and allowed to grow overnight before the addition of IT at different concentrations. After 5 or $24 \mathrm{hr}$ incubation, cells were washed twice with cold phosphate-buffered saline (PBS) containing $0.1 \%$ FCS, and then incubated with $\left[{ }^{3} \mathrm{H}\right]$-leucine $(2$ $\mu \mathrm{Ci} \mathrm{m} l^{-1}$ ) in leucine-free medium at $37^{\circ} \mathrm{C}$ for $45 \mathrm{~min}$. Cells were then washed with $5 \%$ trichloroacetic acid (TCA) for 5 and $10 \mathrm{~min}$, respectively, and dissolved in $0.1 \mathrm{M} \mathrm{KOH}$ for $10-15 \mathrm{~min}$. The resultant solution was transferred to the liquid scintillator. Sample counts were determined in a liquid scintillation counter. Assays were performed in duplicates and repeated at least three times. Counts per minute $(\mathrm{cpm})$ for treated cells were compared to cpm for untreated cells and reported as a percentage of leucine incorporation with the control value set to $100 \%[16]$. The experiment was completed in the isotope laboratory of Nanjing Medical University.

\section{Flow cytometric analysis of cell apoptosis}

Apoptosis were determined by flow cytometric analysis. Briefly, cells in triplicates, were incubated with or without various concentrations of IT for $24 \mathrm{hr}$. Cells were then harvested, washed in cold PBS, and fixed with $1 \mathrm{ml}$ $75 \%$ ice-cold ethanol at $-20^{\circ} \mathrm{C}$ until processing. An aliquot $(1 \mathrm{ml})$ of fixed cell suspension containing $1 \times 10^{6}$ cells was washed twice in cold PBS and then treated with fluorochrome DNA staining solution $(1 \mathrm{ml})$ containing $40 \mu \mathrm{g}$ of propidium iodide and $0.1 \mathrm{mg}$ of RNase $\mathrm{A}$ in the dark at room temperature for $0.5 \mathrm{hr}$. Flow cytometric analysis were performed three times [17].

\section{Caspase activity assay}

Caspase activity was determined in 96-well plates using cell lysates from $1 \times 10^{6}$ cells for each measurement. Caspase- 3 and caspase- 8 activities were determined using colorimetric assay kits according to the 
manufacturer's protocol (BioVision). GES-1, MKN-45 and SGC7901 cells were treated with anti-c-Met/PE38KDEL $(100 \mathrm{ng} / \mathrm{ml})$ for $24 \mathrm{hr}$ prior to the assay. Cell extracts were incubated with $5 \mu \mathrm{l}$ of $4 \mathrm{mM}$ tetrapeptide substrates (DEVD, caspase-3; IETD, and caspase-8) at $37^{\circ} \mathrm{C}$ for $1-2 \mathrm{hr}$. The reaction was measured at $405 \mathrm{~nm}$ in a Microplate Reader. Background readings from cell lysates and buffers were subtracted from the readings of both IT-induced and control samples before calculating the relative change increase in caspase activity in the IT-induced samples compared to that of the control. IT treated samples were normalized to the caspase activity of the untreated sample, which was set to 1.0. Fold of increases in caspase activities were presented.

\section{Statistical analysis}

Statistical analysis was performed with SPSS 13.0 software. Data were presented as mean \pm standard deviation. Student's t-test was used to compare two samples, and the single-factor analysis of variance (One-way ANOVA) was used to compare multiple samples. A pvalue less than 0.05 is considered statistically significant $\left(*, \mathrm{p}<0.05 ;{ }^{* * *}, \mathrm{p}<0.01\right)$.

\section{Results}

Increased c-Met expression in MKN-45 and SGC7901 cells To determine the c-Met protein expression levels in GC, we used western blotting to examine c-Met protein in two GC cells (MKN-45 and SGC7901) and one normal gastric mucosa cells GES-1 (Figure 1A). c-Met proteins is 3-4 fold higher in MKN-45 and SGC7901cells than GES-1 cells. SGC7901 cells express slightly more c-Met than MKN-45 cells (Figure 1B). The optical densities (OD's) of the Western blot bands were measured using ImageJ. The OD for each band was normalized to $\beta$ actin. MKN-45 and SGC7901 had a 0.94 and 1.27 fold increase in the expression of c-Met over the control, but only 0.34 fold increased in GES-1.

\section{IT anti-c-Met/PE38KDEL inhibited cell proliferation and protein synthesis}

GC cells have significantly higher c-Met protein levels than normal gastric mucosa cells, therefore we tried to determine if IT anti-c-Met/PE38KDEL has GC-specific effects. The anti-proliferative effect of IT anti-c-Met/ PE38KDEL on GES-1, MKN-45 and SGC7901 cells was measured using CCK8 kit. Cells were harvested at 24 or $48 \mathrm{hr}$ after IT treatment. As shown in Figure 2, IT inhibited GC cell growth in a time- and dosedependent manner. 1, 10 and $100 \mathrm{ng} / \mathrm{ml}$ of IT caused a dramatic growth inhibition in MKN-45 and SGC7901 cells $(P<0.01) .48 \mathrm{hr}$ of IT treatment $(100$ $\mathrm{ng} / \mathrm{ml}$ ) resulted in a growth inhibition of $30 \%$ in GES1 cells (Figure $2 \mathrm{~A}$ ). However, inhibitions of $75 \%$ and

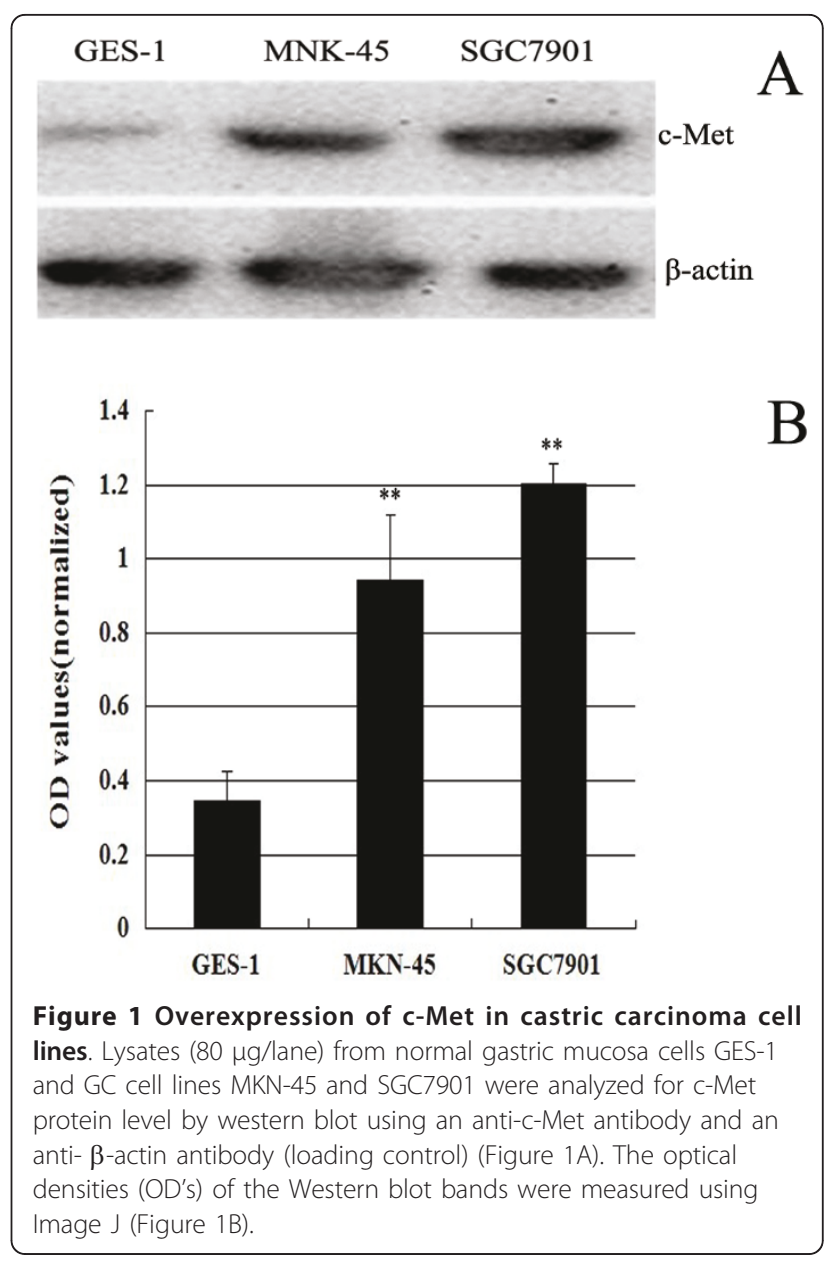

95\% were observed in MKN-45 and SGC7901 cells (Figure 2B and 2C), respectively. Further, we found that there is a strong correlation between c-Met expression and in vitro immunotoxin efficacy.

Given the high c-MET levels in MKN-45 and SGC7910 cell lines, we hypothesize that anti-c-Met/ PE38KDEL can attenuate cancer cell growth through inhibition of protein synthesis via c-Met inhibition. The effects of anti-c-Met/PE38KDEL on protein synthesis in GES-1, MKN-45 and SGC7901 cells are shown in Figure 3. The IT's IC $_{50}$ value on GES-1 cells was approximately $120 \mathrm{ng} / \mathrm{ml}$. However, IT induced more potent inhibitions of protein synthesis in MKN45 and SGC7901 cells, with $\mathrm{IC}_{50}$ values of $5.34 \mathrm{ng} / \mathrm{ml}$ and $0.83 \mathrm{ng} / \mathrm{ml}$, respectively. Nearly $80 \%$ and $100 \%$ of inhibitions were observed with $100 \mathrm{ng} / \mathrm{ml}$ of IT treatment in these two GC cells (Figure 3B and 3C). In contrast, $100 \mathrm{ng} / \mathrm{ml}$ of IT only caused a $35 \%$ decrease in protein synthesis in GES-1 cells (Figure 3A). These results suggested that anti-c-Met/PE38KDEL can attenuate cell growth through the inhibition of protein synthesis. 

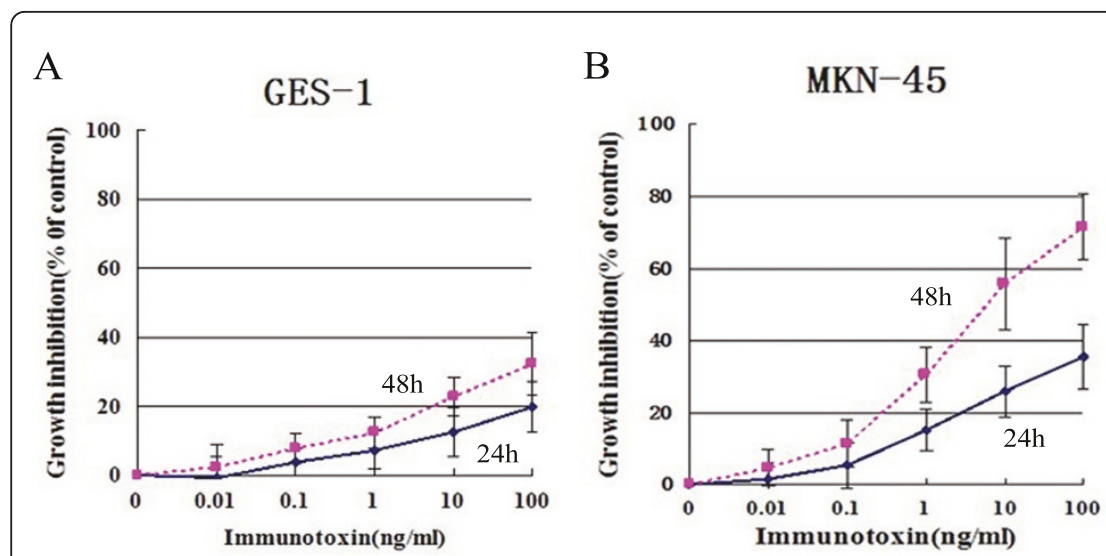

$\mathrm{C}$

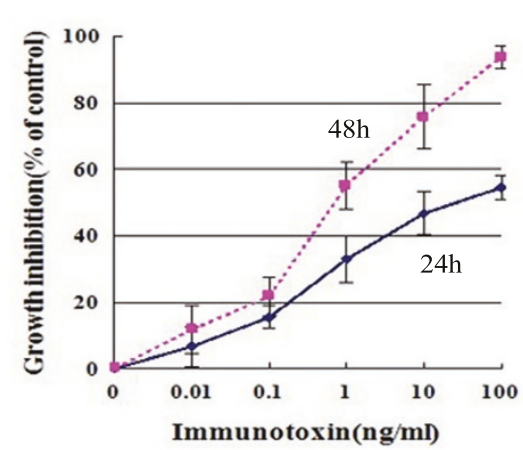

Figure 2 IT anti-c-Met/PE38KDEL induced inhibition of cell proliferation. Cell growth inhibition as a function of varying concentrations of IT (expressed as a percentage of untreated cells), Normal cell GES-1 (A), GC cells MKN-45 (B) and SGC7901 (C) were treated with various concentrations of IT for $24 \mathrm{hr}$ and $48 \mathrm{hr}$.

\section{IT anti-c-Met/PE38KDEL inhibits tumor cell growth} through induction of apoptosis

To determine whether the anti-proliferative effect of IT was due to cell apoptosis, we used flow cytometric (FCM)) to further determine if IT induces cell apoptosis. As shown in Figure 4A and 4B, apoptotic rates in MKN45 and SGC7901 cells were increased from $1.89 \%$ and $2.4 \%(0 \mathrm{ng} / \mathrm{ml})$, to $19.19 \%(\mathrm{P}<0.01)$ and $27.37 \%(\mathrm{P}<$ 0.01) $(50 \mathrm{ng} / \mathrm{ml})$, respectively. The apoptosis rate of GES-1 cells is significantly lower than two GC cells $(5.98 \%, \mathrm{P}<0.01)$ at the IT dose of $50 \mathrm{ng} / \mathrm{ml}$. These data indicate that anti-c-Met/PE38KDEL induced apoptosis in GC cells.

\section{IT anti-c-Met/PE38KDEL activates caspase-3}

To determine whether apoptotic pathway is activated by IT in GC cells, we measured caspase- 3 and caspase- 8 activities following IT treatment. As shown in Figure 5B and 5C, MKN-45 and SGC7901 cells showed 3.70 and 5.02 fold of increases in caspase- 3 enzyme activity as compared to untreated controls after $24 \mathrm{hr}$ IT treatment $(\mathrm{P}<0.01)$. GES-1 exhibited a 2.03 -fold increase in caspase-3 enzyme activity $(\mathrm{P}<0.05)$ (Figure $5 \mathrm{~A})$. Caspase- 8 enzyme activity in two GC cell lines also increased ( $\mathrm{P}<$ $0.05)$, suggesting caspase- 3 activation mediates IT antic-Met/PE38KDEL-induced biological effects.

The caspases are synthesized as inactive precursors (zymogens) that are proteolytically processed to generate active subunits by cleaving specific aspartic acid residues [18], and are essential for the execution process of apoptosis as effector proteases [19]. In the process of IT-inducd apoptosis, caspase- 3 appeared to play a role. We investigated whether caspase-3 is regulated in anti-c-Met/ PE38KDEL-induced cell death. As shown in Figure 6,

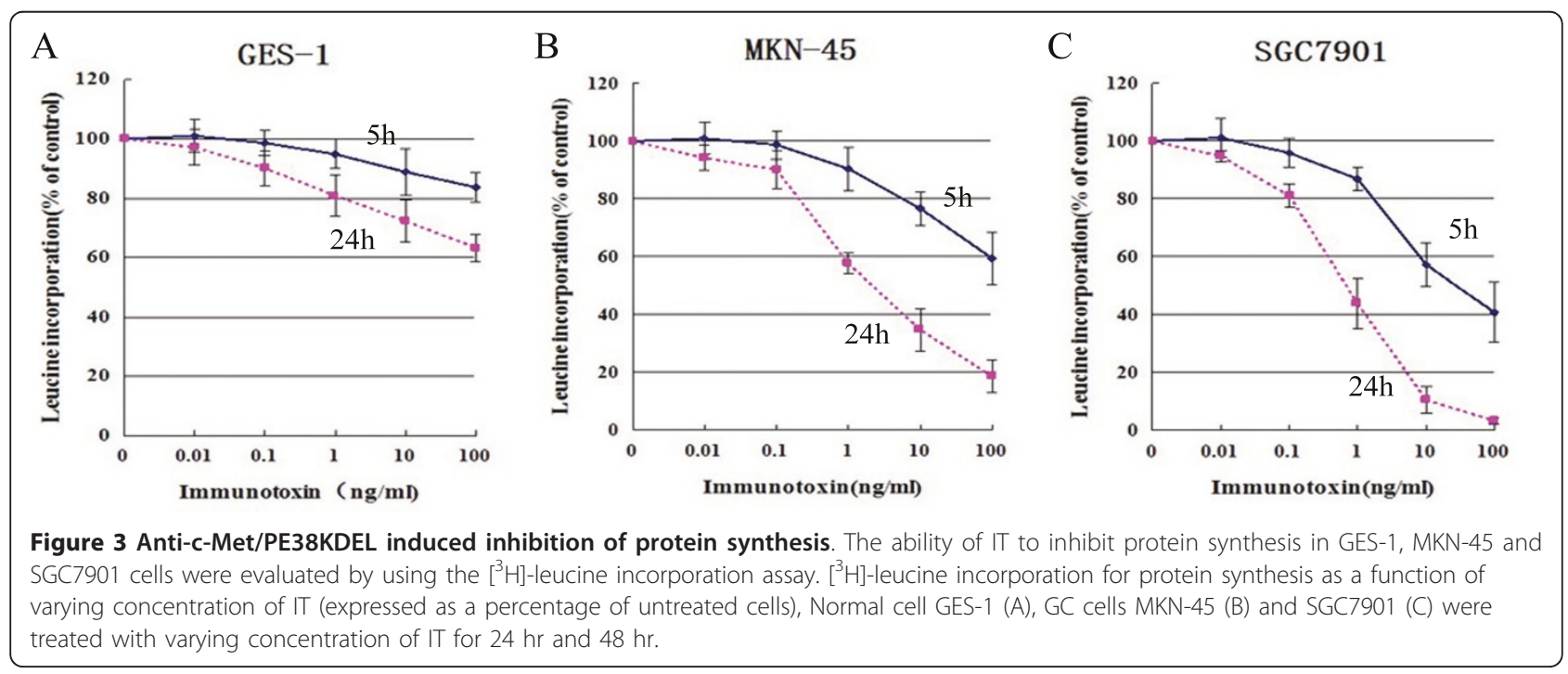



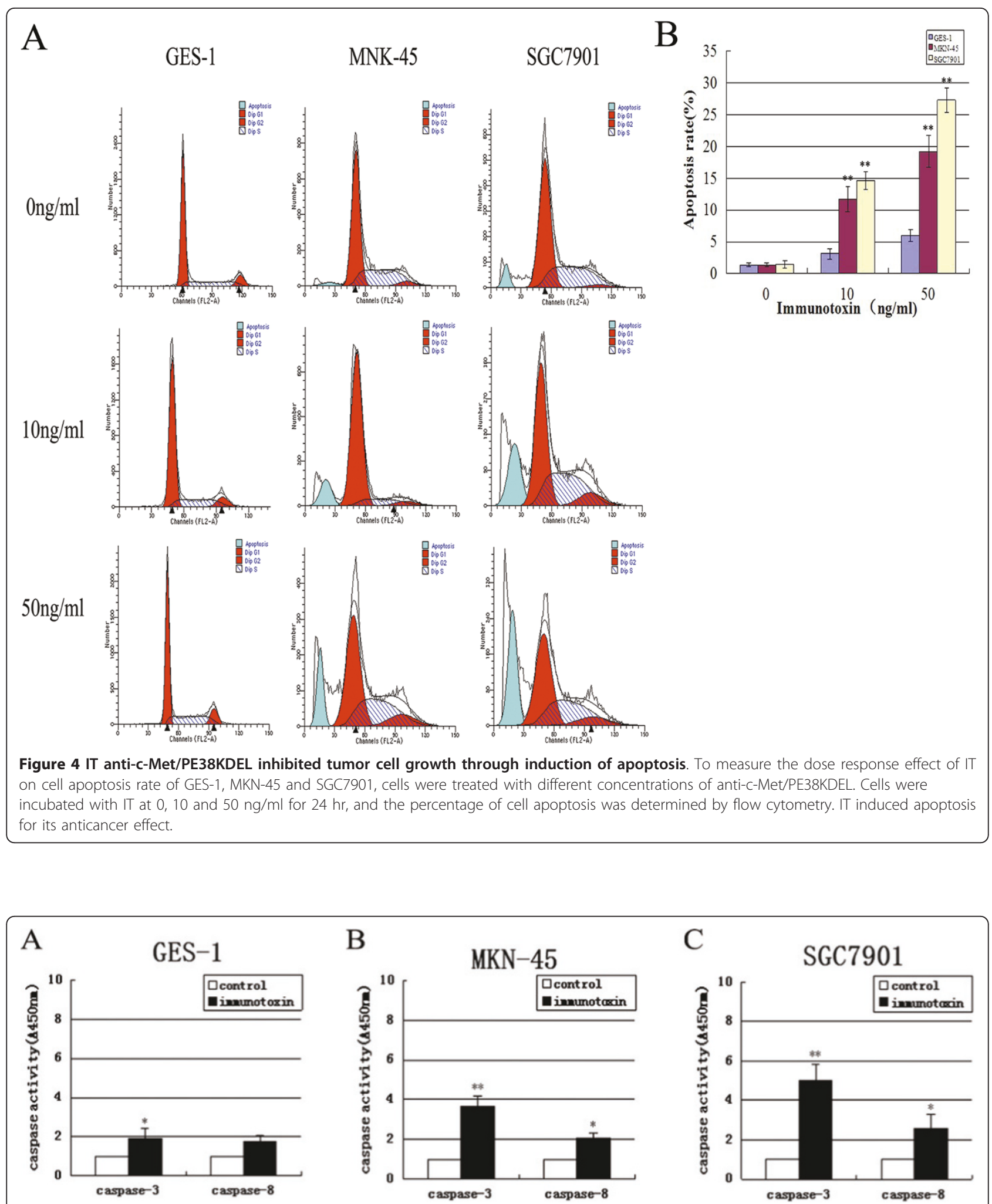

Figure 5 IT anti-c-Met/PE38KDEL mainly activates caspase-3. Caspase-3 and caspase-8 activities in GES-1 (A), MKN-45 (B) and SGC7901 (C) cells were measured in control or IT-treated cells (immunotoxin) (24 hr) using the Caspase colorimetric assay kit. ${ }^{*} P<0.05$, ${ }^{* *} P<0.01$. 


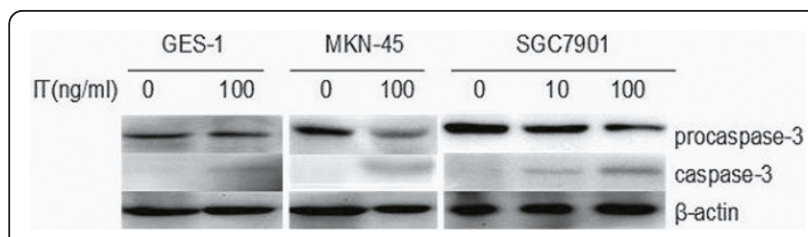

Figure 6 IT-induced caspase 3 cleavage. Lysates from normal gastric mucosa cells GES-1 and GC cell lines MKN-45 and SGC7901 with or without IT treatment were analyzed for procasoase-3 protein levels and activated caspase protein levels by western blot using an anti- procaspase- 3 , anti-activated caspase- 3 and anti- $\beta$ actin antibodies (loading control).

procaspase-3 was proteolytically cleaved in a dose-dependent manner after $24 \mathrm{hr}$ of IT treatment, resulting in the production of the active caspase- 3 fragment $(17 \mathrm{kDa})$. In untreated control cells $(0 \mathrm{ng} / \mathrm{ml})$, no caspase- 3 was detected. All these results suggested that IT anti-c-Met/ PE38KDEL causes apoptosis at least partially via activation of caspase-3.

\section{Discussion}

GC is the second leading cause of cancer mortality in the world [20]. The receptor tyrosine kinase c-Met is constitutively activated in many GCs [2]. Amplifications of c-Met have been associated with human GC progression [21] C-Met is also related to lymph node metastasis in GC [22]. Therefore, c-Met is considered a promsing therapeutic target for this type of cancer [3]. The aim of this study was to evaluate the effects of recombinant immunotoxin anti-c-Met/PE38KDEL on proliferation and apoptosis of GC cells and explore the mechanism underlying the action of anti-c-Met/ PE38KDEL.

SGC7901 was derived from moderately differentiated GC, with a high metastatic potential [23]. MKN-45 was derived from poorly differentiated GC with low metastatic potential [24]. We found that SGC7901 cells expressed high level of c-Met than MKN-45 cells. Normal gastric mucosa cells GES-1 expressed a minimum level of c-Met. Studies have shown that c-Met overexpression in carcinoma cells is associated with liver metastasis of GC [25]. Moreover; c-Met expression can be used as an indicator of liver metastasis for GC patients. It has also been reported that HGF is a lymphangiogenic factor, which can directly or indirectly stimulate lymphangiogenesis and contribute to lymphatic metastasis in GC [26]. Therefore, we hypothesized that IT anti-c-Met/PE38KDEL may be effective in preventing GC's metastasis.

Our data showed that IT decreased GC cell proliferation in a time- and dose-dependent manner. After $48 \mathrm{hr}$ of IT treatment $(100 \mathrm{ng} / \mathrm{ml})$, cell inhibition rate in MKN-45 and SGC7901 cells was about 75\% and 95\%, but only $30 \%$ in GES-1 cells, presumably due to low cMet expression on GES-1 than the two GC cells. IT attenuates cancer cell growth not only by inhibiting protein synthesis but also by inducing apoptosis [27]. We found that IT anti-c-Met/PE38KDEL induced a rapid inhibition of protein synthesis with simultaneous induction of apoptosis in GC cells. Nearly $80 \%$ and $100 \%$ inhibitions of protein synthesis were observed after 24 hr treatment with IT $(100 \mathrm{ng} / \mathrm{ml})$ in the MKN-45 and SGC7901 cells, respectively. The inhibition was much less pronounced in GES-1 cells (35\%), suggesting that IT anti-c-Met/PE38KDEL is selective against GC. In addition, IT exerts its anticancer effect mostly via induction of cells apoptosis. The apoptosis rates in three cells were all increased after treatment with IT, more prominent in the two GC cell lines.

Caspases are classified into two functional subgroups-initiator caspases and effector caspases. The initiator caspases are caspase 2, 8, 9 and 10, and the effector caspases are caspase 3, 6 and 7 [28]. Caspases are critical mediators of apoptosis [29]. Activation of caspase is responsible for multiple molecular and structural changes in apoptosis [30]. Caspase-3 is a potent effector of apoptosis in a variety of cells [31] and plays a central role in both death-receptor and mitochondria-mediated apoptosis. Caspase- 8 is the prototypical apoptosis initiator downstream of TNF super-family death receptors. Our data showed that caspase-3 enzyme activity exhibited 3.70, and 5.02 fold increases in IT-treated MKN-45 and SGC7901 cells as compared to the activity of untreated controls $(\mathrm{P}<$ 0.01 ). The increase in caspase- 8 enzyme activity was less significant.

\section{Conclusions}

Our results demonstrate the time- and dose-dependent anti-growth effects of IT anti-c-Met/PE38KDEL against GC cell lines. The anti-cancer effect of IT occurred primarily through inhibition of protein synthesis, and caspase-3-mediated apoptosis, suggesting the potential value of IT as an anti-c-MET therapeutics for GC.

\section{Abbreviations \\ IT: Immunotoxins; GC: Gastric carcinoma; HGF: hepatocyte growth factor; CCK8: Cell Counting Kit 8; FCS: fetal calf serum; TBS: Tris-buffered saline; IR: inhibition rate; PBS: phosphate-buffered saline; SDS: sodium dodecyl sulphate; PAGE: polyacrylamide gel electrophoresis.}

\section{Acknowledgements and Funding}

This study was funded by nature science founation of jiangsu province (BK2008483).

\section{Author details}

${ }^{1}$ Department of Gastroenterology, The Second Affiliated Hospital of Nanjing Medical University, Nanjing, 210029, PR China. ${ }^{2}$ Department of Pathology, Nanjing Medical University, Nanjing, 210029, PR China. 


\section{Authors' contributions}

LZ AND XW: Conceived, designed, and coordinated the study and acquired the necessary funding; and carried out the majority of the in vitro studies. drafted the manuscript. CN and ZXJ: carried out all subsequent analyses; FXM: carried out some of the in vitro experiments; ZXH and FZQ: Contributed to the design and coordination of the study and aided with manuscript preparation. All authors read and approved the final manuscript.

\section{Competing interests}

The authors declare that they have no competing interests.

Received: 16 May 2011 Accepted: 7 July 2011 Published: 7 July 2011

\section{References}

1. Tepes B: Can gastric cancer be prevented? J Physiol Pharmacol 2009, 60:71-77.

2. Gubanski M, Johnsson A, Fernebro E, Kadar L, Karlberg I, Flygare P, Berglund A, Glimelius B, Lind PA: Randomized phase II study of sequential docetaxel and irinotecan with 5-fluorouracil/folinic acid (leucovorin) in patients with advanced gastric cancer: the GATAC trial. Gastric Cancer 2010, 13:155-161.

3. Corso S, Ghiso E, Cepero V, Sierra JR, Migliore C, Bertotti A, Trusolino L, Comoglio PM, Giordano S: Activation of HER family members in gastric carcinoma cells mediates resistance to MET inhibition. Mol Cancer 2010, 9:121.

4. Tahara E: Cancer-stromal interaction through growth factor/cytokine networks implicated in growth of stomach cancer. Princess Takamatsu Symp 1994, 24:187-194.

5. Bottaro DP, Rubin JS, Faletto DL, Chan AM, Kmiecik TE, Vande Woude GF, Aaronson SA: Identification of the hepatocyte growth factor receptor as the c-met proto-oncogene product. Science 1991, 251:802-804.

6. Drebber U, Baldus SE, Nolden B, Grass G, Bollschweiler E, Dienes HP, Hölscher AH, Mönig SP: The overexpression of c-met as a prognostic indicator for gastric carcinoma compared to p53 and p21 nuclear accumulation. Oncol Rep 2008, 19:1477-1483.

7. Liu SI, Chi CW, Lui WY, Mok KT, Wu CW, Wu SN: Correlation of hepatocyte growth factor-induced proliferation and calcium-activated potassium current in human gastric cancer cells. Biochim Biophys Acta 1998, 1368:256-266.

8. Kreitman RJ: Recombinant immunotoxins containing truncated bacterial toxins for the treatment of hematologic malignancies. BioDrugs 2009, 23:1-13.

9. Martínez-Torrecuadrada JL, Cheung LH, López-Serra P, Barderas R, Cañamero M, Ferreiro S, Rosenblum MG, Casal Jl: Antitumor activity of fibroblast growth factor receptor 3-specific immunotoxins in a xenograft mouse model of bladder carcinoma is mediated by apoptosis. Mol Cancer Ther 2008, 7:862-873.

10. Zhu XJ, Feng ZQ, Zhu J, Tang qi, Liu zheng: Construction, expression and purification of an immunotoxin containing a human anti-c-Met singlechain antibody fused to PE38KDEL. Acta Univ Med Nanjing 2009, 29:920-924.

11. Kitamura S, Miyazaki Y, Hiraoka S, Toyota M, Nagasawa Y, Kondo S, Kiyohara T, Shinomura Y, Matsuzawa Y: PPARgamma inhibits the expression of c-MET in human gastric cancer cells through the suppression of Ets. Biochem Biophys Res Commun 1999, 265:453-456.

12. Kaji M, Yonemura Y, Harada S, Liu X, Terada I, Yamamoto H: Participation of c-met in the progression of human gastric cancers: anti-c-met oligonucleotides inhibit proliferation or invasiveness of gastric cancer cells. Cancer Gene Ther 1996, 3:393-404.

13. Zheng S, Ke Y: Study of APC, Rb, c-met gene copy numbers of human gastric mucosa epithelial cell line GES-1. Zhonghua Zhong Liu Za Zhi 1999, 21:409-411.

14. Koyama M, Izutani Y, Goda AE, Matsui TA, Horinaka M, Tomosugi M, Fujiwara J, Nakamura Y, Wakada M, Yogosawa S, Sowa Y, Sakai T: Histone deacetylase inhibitors and 15-deoxy-Delta12,14-prostaglandin J2 synergistically induce apoptosis. Clin Cancer Res 2010, 16:2320-2332.

15. Risberg K, Fodstad $\varnothing$, Andersson Y: The melanoma specific 9.2.27PE immunotoxin efficiently kills melanoma cells in vitro. Int J Cancer 2009, 125:23-33.

16. Andersson $Y$, Juell $S$, Fodstad Ø: Downregulation of the antiapoptotic MCL-1 protein and apoptosis in MA-11 breast cancer cells induced by an anti-epidermal growth factor receptor-Pseudomonas exotoxin a immunotoxin. Int J Cancer 2004, 112:475-483.

17. Li Z, Li J, Mo B, Hu C, Liu H, Qi H, Wang X, Xu J: Genistein induces G2/M cell cycle arrest via stable activation of ERK1/2 pathway in MDA-MB-231 breast cancer cells. Cell Biol Toxicol 2008, 24:401-409.

18. Yamashima T: Implication of cysteine proteases calpain, cathepsin and caspase in ischemic neuronal death of primates. Prog Neurobiol 2000, 62:273-295.

19. Cohen GM: Caspases: the executioners of apoptosis. Biochem J 1997, 326:1-16.

20. Wagner $A D$, Wedding $U$ : Advances in the pharmacological treatment of gastro-oesophageal cancer. Drugs Aging 2009, 26:627-646.

21. Asaoka Y, Tada M, Ikenoue T, Seto M, Imai M, Miyabayashi K, Yamamoto K, Yamamoto S, Kudo Y, Mohri D, Isomura Y, liichi H, Tateishi K, Kanai F, Ogawa S, Omata M, Koike K: Gastric cancer cell line Hs746T harbors a splice site mutation of c-Met causing juxtamembrane domain deletion. Biochem Biophys Res Commun 2010, 394:1042-1046.

22. Lee SW, Kang SB, Kim YS, Nam SW, Lee DS, Lee HK, Han SW: Expression of c-erbB-2 and c-met proteins in gastric adenoma and adenocarcinoma. Korean J Gastroenterol 2007, 49:152-157.

23. Pan Y, Zhao L, Liang J, Liu J, Shi Y, Liu N, Zhang G, Jin H, Gao J, Xie H, Wang J, Liu Z, Fan D: Cellular prion protein promotes invasion and metastasis of gastric cancer. FASEB J 2006, 20:1886-1888.

24. Rege-Cambrin G, Scaravaglio P, Carozzi F, Giordano S, Ponzetto C, Comoglio PM, Saglio G: Karyotypic analysis of gastric carcinoma cell lines carrying an amplified c-met oncogene. Cancer Genet Cytogenet 1992, 64:170-173.

25. Amemiya H, Kono K, Itakura J, Tang RF, Takahashi A, An FQ, Kamei S, lizuka H, Fujii H, Matsumoto Y: c-Met expression in gastric cancer with liver metastasis. Oncology 2002, 63:286-296.

26. Zhang QH, Qian K, Li XJ, Pu J, Wu XT: Experimental study of the hepatocyte growth factor contributing to lymphangiogenesis and lymphatic metastasis in gastric cancer. Zhonghua Wei Chang Wai Ke Za Zhi 2007, 10:212-216.

27. Polito L, Bolognesi A, Tazzari PL, Farini V, Lubelli C, Zinzani PL, Ricci F, Stirpe F: The conjugate Rituximab/saporin-S6 completely inhibits clonogenic growth of $\mathrm{CD} 20$-expressing cells and produces a synergistic toxic effect with Fludarabine. Leukemia 2004, 18:1215-1222.

28. Kim MS, Park SW, Kim YR, Lee JY, Lim HW, Song SY, Yoo NJ, Lee SH: Mutational analysis of caspase genes in prostate carcinomas. APMIS 2010, 118:308-312

29. Zhou XX, Ji F, Zhao JL, Cheng LF, Xu CF: Anti-cancer activity of antip185HER-2 ricin A chain immunotoxin on gastric cancer cells. J Gastroenterol Hepatol 2010, 25:1266-1275.

30. Chen L, Zhuang G, Li W, Liu Y, Zhang J, Tian X: RGD-FasL induces apoptosis of pituitary adenoma cells. Cell Mol Immunol 2008, 5:61-68

31. Alnemri ES, Livingston DJ, Nicholson DW, Salvesen G, Thornberry NA, Wong WW, Yuan J: Human ICE/CED-3 protease nomenclature. Cell 1996, 87:171.

doi:10.1186/1756-9966-30-67

Cite this article as: Wei et al: Recombinant immunotoxin anti-c-Met/ PE38KDEL inhibits proliferation and promotes apoptosis of gastric cancer cells. Journal of Experimental \& Clinical Cancer Research 2011 30:67.

\section{Submit your next manuscript to BioMed Central and take full advantage of:}

- Convenient online submission

- Thorough peer review

- No space constraints or color figure charges

- Immediate publication on acceptance

- Inclusion in PubMed, CAS, Scopus and Google Scholar

- Research which is freely available for redistribution 